\title{
Economic Uncertainty and European Solidarity: Public Opinion Trends
}

\author{
By RoNALD INGLEHART AND JACQUES-RENÉ RABIER
}

ABSTRACT: Impressive growth in public support for the European Community took place during the decade following its founding; there is reason to believe that this development was partly due to the exceptional prosperity then prevailing in the Community's member nations. Conversely, there is evidence that the troubled economic conditions present since expansion of the Community in 1973 have had the opposite effect-subject to some important limiting factors. Analysis of public opinion survey data reveals a positive correlation between support for Community membership and a given nation's level of industrial production at a given time point; and a negative correlation with rates of inflation. Nevertheless, long-term influences seem to dominate the effects of the immediate economic context. Among these long-term factors, length of membership in the Community seems particularly important. But the presence of "Post-Materialist" value priorities, and of relatively high levels of "Cognitive Mobilization" also show significant linkages with public support for European integration.

Ronald Inglehart is Professor of Political Science at The University of Michigan and currently Visiting Professor of Political Science at the University of Mannheim, Germany. Author of The Silent Revolution: Changing Values and Political Styles among Western Publics, he has collaborated with Rabier since 1969 in the design and analysis of European public opinion surveys.

Jacques-René Rabier is a special advisor to the Commission of the European Communities. Since 1974, he has been responsible for the Community's program of public opinion research, conducting surveys in each of the nine nations twice each year. The author of numerous articles on mass attitudes and European integration, he has served in a variety of posts, most recently as Director-General for Information of the Commission of the European Communities. 
$I^{\prime}$ N THE Spring of 1979, the electorates of nine nations will vote for their representatives in the first directly-elected European Parliament in history. This event constitutes a major advance for public involvement in shaping the European Community, for European integration was initially a process that was almost exclusively restricted to collaboration between a relative handful of highly-placed elites. With the national referenda of 1972 and 1975, when membership or nonmembership in the European Community for Ireland, Norway, Denmark and Great Britain was decided by the electorates of the four respective countries, it marked the first public ratification of a European integration effort. The European Parliament will place the affairs of the Community under the permanent scrutiny of representatives elected by the voters of all nine member countries. It is a good time to take stock of the evolution of mass attitudes toward Europe's supranational institutions.

To date, these institutions have been all too remote from the general public, being guided exclusively by appointed officials. As a result, they have lacked the political base and the democratic legitimacy that might justify their playing a more important role in dealing with some of the major problems that currently beset the European Community as a whole. By themselves, direct elections will not clear the way for a greater degree of European decisionmaking, but they could facilitate this development. Whether they do so or not depends on how much backing the publics of the nine nations accord the European institutions, and whether they are ready to support decisionmakers who act at the European level, with an eye to the interests of the European Community as a whole rather than an exclusive focus on the interests of a particular nation. This article will analyze relevant trends in mass attitudes toward European integration, in an effort to interpret these trends and some of the factors underlying them.

\section{Public Evaluations of MEMBERSHIP IN THE EXPANDED EUROPEAN COMMUNITY}

The decade following the founding of the European Economic Community in 1958 was a period of unprecedented prosperity and high expectations. During these years, support for European unification among the publics of the original six member nations showed a clear tendency toward upward convergence. At first, sharply divided along Left-Right lines, the French and Italian publics gradually moved toward a pro-European consensus that extended across the political spectrum, bringing them up to the initially higher levels of support that prevailed among the publics of Germany, The Netherlands, Belgium and Luxembourg. This evolution seems to have been favored by the prosperity then prevailing, which tended (rightly or wrongly) to be attributed in part to membership in the European Community.

The British public remained outside the Community during this period, at first by the choice of their own government, and subsequently as a result of two successive Gaullist vetoes of British entry. The general contours of the flow of public opinion from 1952 to 1975 are indicated by Figure 1; the process 


\section{FIGURE 1}

THE EVOLUTION OF SUPPort For EUROPEAN UNIFICATION, 1952-1975.

Based on percent "for" "efforts to unify Europe." Missing data are included in percentage base; thus, in 1952, 70 percent of the German public was "for," 10 percent "against" and 20 percent "undecided" or "no opinion."

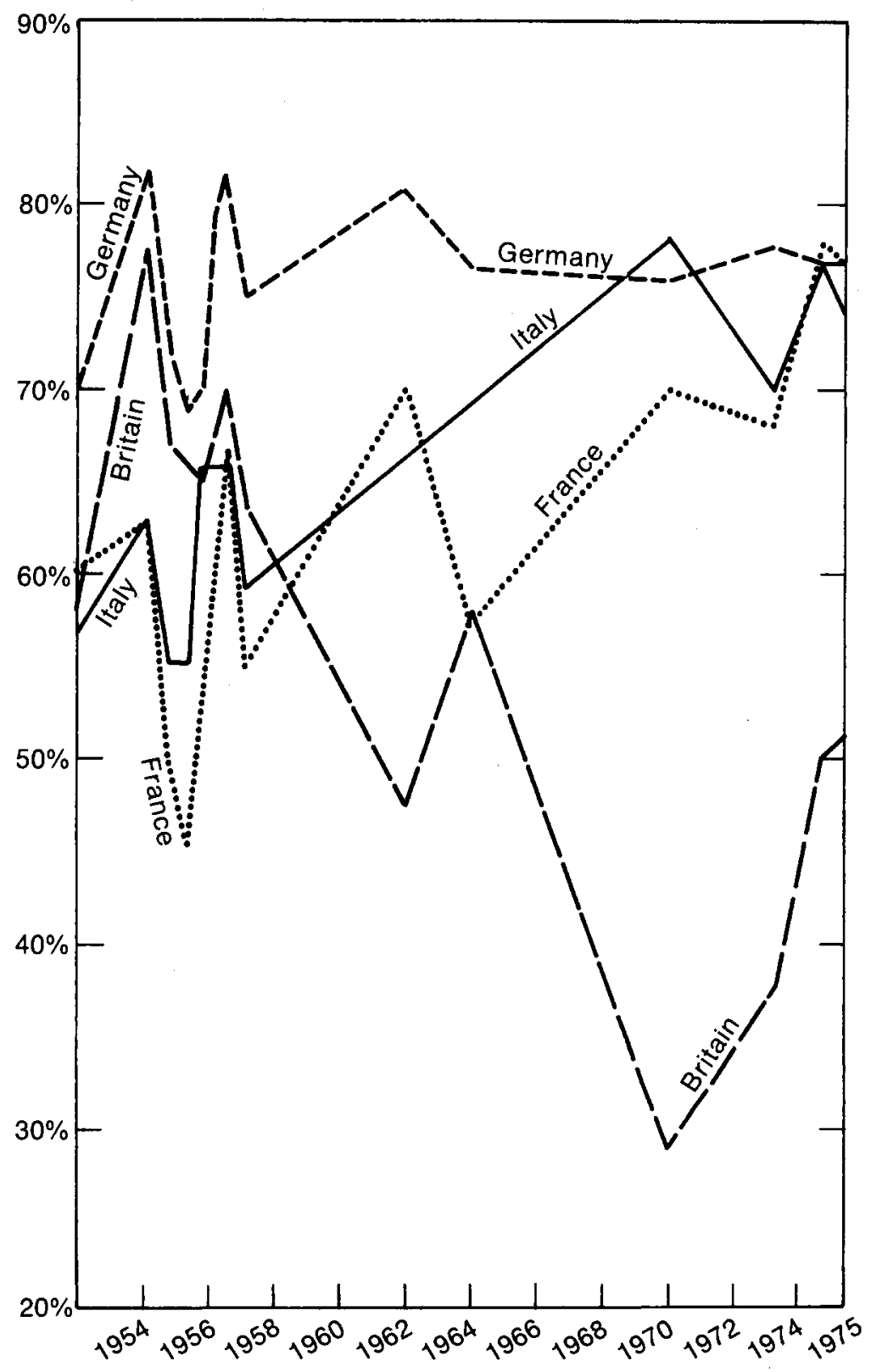


has been examined elsewhere in greater detail. ${ }^{1}$

The expanded nine-nation European Community came into being in 1973 , on the eve of the most serious economic recession since the 1930s. In sharp contrast to the prosperity of the Community's early years, the publics of the expanded Community have experienced varying degrees of economic stagnation, accompanied by extraordinarily high inflation, and the highest levels of unemployment since the immediate postwar era.

Though they differ in detail, almost all of the major theorists who have worked in this area concur that favorable economic payoffs are conducive to-and perhaps even essential to-the processes of national and supranational integration. ${ }^{2}$ Similarly, David Easton views mass support for a political system

1. See Ronald Inglehart, The Silent Revolution: Changing Values and Political Styles Among Western Publics (Princeton: Princeton University Press, 1977), Chap. 12.

2. See Ernst B. Haas, The Uniting of Europe (Stanford, CA: Stanford University Press, 1958); Ernst B. Haas and Phillipe C. Schmitter, "Economics and Differential Patterns of Political Integration: Projections About Unity in Latin America," International Organization, vol. 18 (Autumn 1964), pp. 705-37; Karl W. Deutsch, et al., Political Community and The North Atlantic Area (Princeton: Princeton University Press, 1957); Leon N. Lindberg and Stuart A. Scheingold, Europe's Would-Be Polity (Englewood Cliffs, NJ: Prentice-Hall, 1970); Joseph S. Nye, Jr., "Comparative Regional Integration: Concept and Measurement," International Organization, vol. 22 (Autumn 1968), pp. 855-80; Lindberg and Scheingold, eds., Regional Integration: Theory and Research (Cambridge, MA: Harvard University Press, 1971); Amitai Etzioni, Political Unification (New York: Holt, Rinehart and Winston, 1965); Philip E. Jacob and James V. Toscano, eds., The Integration of Political Communities (Philadelphia: Lippincott, 1964); and Charles Pentland, International Theory and European Integration (New York: The Free Press, 1973). as the result of positive governmental outputs. In time, a series of outputs that are perceived as beneficial may build up a reservoir of "diffuse support" that is not contingent on immediate payoffs, but the generation of diffuse support can be traced back to favorable outputs at an earlier time, with economic outputs being the most obvious type and perhaps the most widely appreciated one. ${ }^{3}$ Has mass support for the European Community institutions continued to develop in the uncertain economic climate that has prevailed since 1973 , or has there been a growing sense of disenchantment?

It seems that both things have occurred in connection with different aspects of mass attitudes. In order to grasp what has been happening, it is important to distinguish between diffuse or "affective" support and "utilitarian" support-a calculated appraisal of the immediate costs and benefits of membership in the Community. ${ }^{4}$ The latter seems to have moved downhill to some extent from 1973 to 1977 , though with important cross-national differences in how far it went. But along with this development, a sense of solidarity among the nine nations of the European Community has emerged among all nine publicsa solidarity that includes a sur-

3. See David Easton, A Framework for Political Analysis (Englewood Cliffs, NJ: Prentice-Hall, 1965), pp. 124-26. Cf. Seymour M. Lipset, "Some Social Requisites of Democracy: Economic Development and Political Legitimacy," American Political Science Review 53, 1 (March, 1959).

4. For a discussion of utilitarian support versus affective support, see David Handley, "Public Support for European Integration" (Ph.D. diss., University of Geneva, 1975); cf. Werner Feld and John Wildgen, Domestic Political Realities and European Integration (Boulder, CO: Westview Press, 1976). 
prisingly widespread willingness to share economic burdens in time of difficulties, and a certain readiness to place the interests of the Community as a whole above those of one's own nation. It may be that the sheer passage of time under common supranational institutions - provided they are entered into voluntarily-gradually instils the habit of viewing things from a perspective broader than that of the nation-state, even in the absence of material rewards.

As Deutsch has suggested, symbolic rewards can sometimes substitute for economic ones, and the experience of struggle against common difficulties can encourage a sense of solidarity even in times of adversity. ${ }^{5}$ In short: unfavorable economic conditions seem to have engendered a decline in the prevalence of positive assessments of membership, but they have not prevented the growth of a sense of European Community solidarity. Let us examine the evidence on both points.

In late October and early November of 1977, representative national samples of the publics of the nine European Community countries were interviewed as part of a regular program of surveys carried out twice each year under the sponsorship of the Commission of the European Community. ${ }^{6}$ The respondents were

5. See Karl W. Deutsch, Political Community, Chap. 3.

6. Field work for the Euro-Barometer series has been carried out by the European Omnibus Survey-a consortium consisting of the European affiliates of the Gallup survey group-except in Belgium and Luxembourg where the surveys were conducted by INRA. In these surveys, samples of approximately 1,000 respondents are interviewed in each country except Luxembourg, where the $\mathrm{N}$ is approximately 300 ; and in the United Kingdom, where 1,000 respondents are interviewed in Great Britain and 300 respondents are interviewed in Northern asked: "Generally speaking, do you think that (your country's) membership in the Common Market is a good thing, a bad thing, or neither good nor bad?" This question is phrased in a way that makes it easy for those who have no clear opinion to select the neutral option. Dimensional analysis of data from earlier surveys indicated that this item was a good indicator of responses to a broad cluster of attitudes concerning support for, or opposition to, European integration. Consequently, this item was included as a standard question in all subsequent European Community surveys. The distribution of responses in Fall, 1977 appears in Table 1.

In the Community as a whole, a clear majority felt that their country's membership was a good thing,

Ireland. The organizations responsible for fieldwork in each country are: DIMARSO/ INRA (Luxembourg and Belgium); Gallup Markedanalyse (Denmark); EMNID-Institut (Germany); Institut Francais d'Opinion Publique (France); Irish Marketing Surveys (Ireland); Instituto per le Richerche Statistische e l'Analyisi dell'Opinione Publica (DOXA-Italy); Nederlands Institut voor de Publieke Opinie (NIPO-Netherlands); and Social Surveys Ltd. (Gallup Poll-Great Britain). Fieldwork in Northern Ireland is conducted jointly by Irish Marketing Surveys and Social Surveys (Gallup Poll). In Germany, fieldwork for the 1973 survey was carried out by Gesellschaft für Marktforschung and for the 1970 survey by Institut für Demoskopie. In Britain, the 1970 survey was conducted by Louis Harris Research, Ltd. In the Netherlands, the 1973 survey was carried out by Nederlandse Stichting voor Statistiek. International coordination of the Euro-Barometer surveys is directed by Helène Riffault of IFOP and Norman Webb of Social Surveys (Gallup Poll). Fieldwork for the Fall, 1977 survey took place from October 24 to November 8 , 1977. For a more detailed report of findings from this survey, see Commission of the European Communities, Euro-Barometer Number 8: Public Opinion in the European Community (Brussels: European Community [mimeo], 1978). 
TABLE 1

Public Appraisal of Their Nation's Membership in the European COMMUNITY: FALL, 1977

\begin{tabular}{|c|c|c|c|c|c|c|c|c|c|c|}
\hline $\begin{array}{c}\text { FEEL THAT } \\
\text { THEIR NATION'S } \\
\text { MEMBERSHIP IS: }\end{array}$ & FaAnce & BELG. & Neth. & $\begin{array}{l}\text { GER- } \\
\text { MANY }\end{array}$ & ITALY & LUX. & $\begin{array}{l}\text { DEN- } \\
\text { MAAK }\end{array}$ & $\begin{array}{l}\text { IRE- } \\
\text { LAND }\end{array}$ & UK & $\begin{array}{l}\text { EURO- } \\
\text { PEAN } \\
\text { COM- } \\
\text { MUNITY* }\end{array}$ \\
\hline \multicolumn{11}{|l|}{ Total } \\
\hline Respondents & (1004) & (1006) & (943) & (999) & $(1155)$ & (344) & (992) & (997) & (1351) & (8791) \\
\hline A Good Thing & $57 \%$ & 60 & 74 & 59 & 70 & 73 & 37 & 59 & 35 & 56 \\
\hline $\begin{array}{l}\text { A Bad Thing } \\
\text { Neither Good }\end{array}$ & 9 & 5 & 5 & 7 & 5 & 3 & 33 & 19 & 37 & 14 \\
\hline $\begin{array}{l}\text { Neither Good } \\
\text { Nor Bad }\end{array}$ & 28 & 19 & 16 & 24 & 18 & 17 & 24 & 19 & 23 & 23 \\
\hline Don't Know & 6 & 16 & 5 & 10 & 7 & 7 & 6 & 3 & 5 & 7 \\
\hline
\end{tabular}

"Each national sample weighted in proportion to that nation's population.

with positive assessments outweighing negative ones by a four-to-one ratio even in this relatively uncertain economic context. But a marked contrast is apparent when we compare the appraisal given by the publics of the six original member countries with those of the three new members. In both Denmark and the United Kingdom, positive and negative evaluations are almost evenly balanced, with negative ratings actually outweighing positive ones in the latter country. The third new member public, the Irish, manifest a much more favorable attitude but even there negative appraisals are more than twice as numerous as in any of the original six nations. The fact that Ireland is relatively favorable is not particularly surprising: adherence to the Common Market has secured entry on favorable terms to a large market for Irish agricultural products something particularly important for a country that is still heavily agrarian. Moreover, Irish membership seems to have encouraged a boom in industrial development, linked with the fact that Ireland has one of the lowest costs for industrial production of any region within the European Community.
Nevertheless, the overall pattern cannot be attributed solely to differences in currently prevailing economic conditions. All nine countries have suffered seriously from the effects of the recent recession. The striking difference in the balance of positive and negative appraisals between the original six and the three new member countries seems to reflect the presence or absence of a reservoir of diffuse support built up over a long period of time, raising evaluations among the six well above the level that would be expected on the basis of current economic factors alone.

How resistant is such support to decay in the face of adverse current conditions? Table 2 shows the percentage making a positive appraisal of their country's membership in the Common Market, in each nation, for each of the nine time points at which the current series of surveys has been conducted. As a detailed inspection of these results shows, positive evaluations remained at relatively high levels in each of the original six member nations throughout the period from 1973 through 1977. Positive appraisals have, on the whole, been much less widespread in the three 
new member countries; and their support levels have shown somewhat greater volatility over time, as if they were more responsive to current influences. Figure 2 provides a graphic presentation of the data in Table 2, combining the results from the six in an average weighted according to population. The graph reveals a pattern that may be more difficult to see in Table 2. Though the oscillations are greater among the publics of the three new members than among the six, there is a certain parallelism in the rise and fall of attitudes toward Common Market membership in both sets of countries: favorable assessments reach a peak in Fall 1975, plummet to a low point in 1976 and then show a tendency to recover in 1977. This pattern bears an interesting relationship to the rise and fall of the Index of Industrial Production for the respective nations, which is shown in Figure 3.

Let us assume that public assessments of the Common Market have been influenced, at least to some extent, by the economic fortunes of the respondent's country, of which the Index of Industrial Pro- duction is one indicator. If this is the case, we must note that there is a lag of about a year between changes in our economic indicator and changes in mass attitudes. With the onset of the recent recession, the Index of Industrial Production declined, sometimes precipitously, in all nine countries, reaching a low point in 1975-the year in which positive evaluations of the Common Market were at a peak. Industrial production made a subsequent recovery, with most nations regaining or surpassing their 1973 levels by the Fall of 1976-when public assessments in most countries were at their low point. Needless to say, there were cross-national deviations from the general pattern; on the whole, they reflect changes in industrial production reasonably well. On one hand, the recovery of favorable attitudes has been relatively weak and occurred relatively late in Britain - which accords with the fact that British industrial production in 1977 was still below its 1973 level. Conversely, the recession had a comparatively mild impact on Ireland's economy. To be sure, her per capita

TABLE 2

Public Appraisal of Membership in the European Community, 1973-1977 (Percentage Saying That Their Country's Membership IS "A GOOD THING")

\begin{tabular}{|c|c|c|c|c|c|c|c|c|c|}
\hline & $\begin{array}{l}\text { FALL } \\
1973\end{array}$ & $\begin{array}{c}\text { SPRING } \\
1974\end{array}$ & $\begin{array}{l}\text { FALL } \\
1974\end{array}$ & $\begin{array}{c}\text { SPAING } \\
1975\end{array}$ & $\begin{array}{l}\text { FALL } \\
1975\end{array}$ & $\begin{array}{c}\text { SPRING } \\
1976\end{array}$ & $\begin{array}{l}\text { FALL } \\
1976\end{array}$ & $\begin{array}{c}\text { SPRING } \\
1977\end{array}$ & $\begin{array}{l}\text { FALL } \\
1977\end{array}$ \\
\hline France & $61 \%$ & 68 & 63 & 64 & 67 & 57 & 52 & 64 & 57 \\
\hline Belgium & 57 & 68 & 60 & 57 & 59 & 62 & 66 & 69 & 60 \\
\hline Netherlands & 63 & 66 & 70 & 64 & 67 & 75 & 74 & 80 & 74 \\
\hline Germany & 63 & 59 & 62 & 56 & 61 & 48 & 57 & 54 & 59 \\
\hline Italy & 69 & 77 & 82 & 71 & 75 & 63 & 68 & 71 & 70 \\
\hline Luxembourg & 67 & 79 & 73 & 65 & 78 & 66 & 77 & 84 & 73 \\
\hline Denmark & 42 & 35 & 33 & 36 & 41 & 36 & 29 & 30 & 37 \\
\hline Ireland & 56 & 48 & 50 & 50 & 67 & 50 & 50 & 57 & 59 \\
\hline $\mathrm{UK}^{*}$ & 31 & 33 & 36 & 47 & 50 & 39 & 39 & 35 & 35 \\
\hline
\end{tabular}

* Surveys were carried out in Great Britain only, in 1973 and 1974; from 1975 on, the figures for the "United Kingdom" include Northern Ireland as well. 
FIGURE 2

APPRAISAL OF MEMBERSHIP IN COMMON MARKET, 1973-1977.

Percentage Saying That Their Country's Membership Is "A GOOD THING."

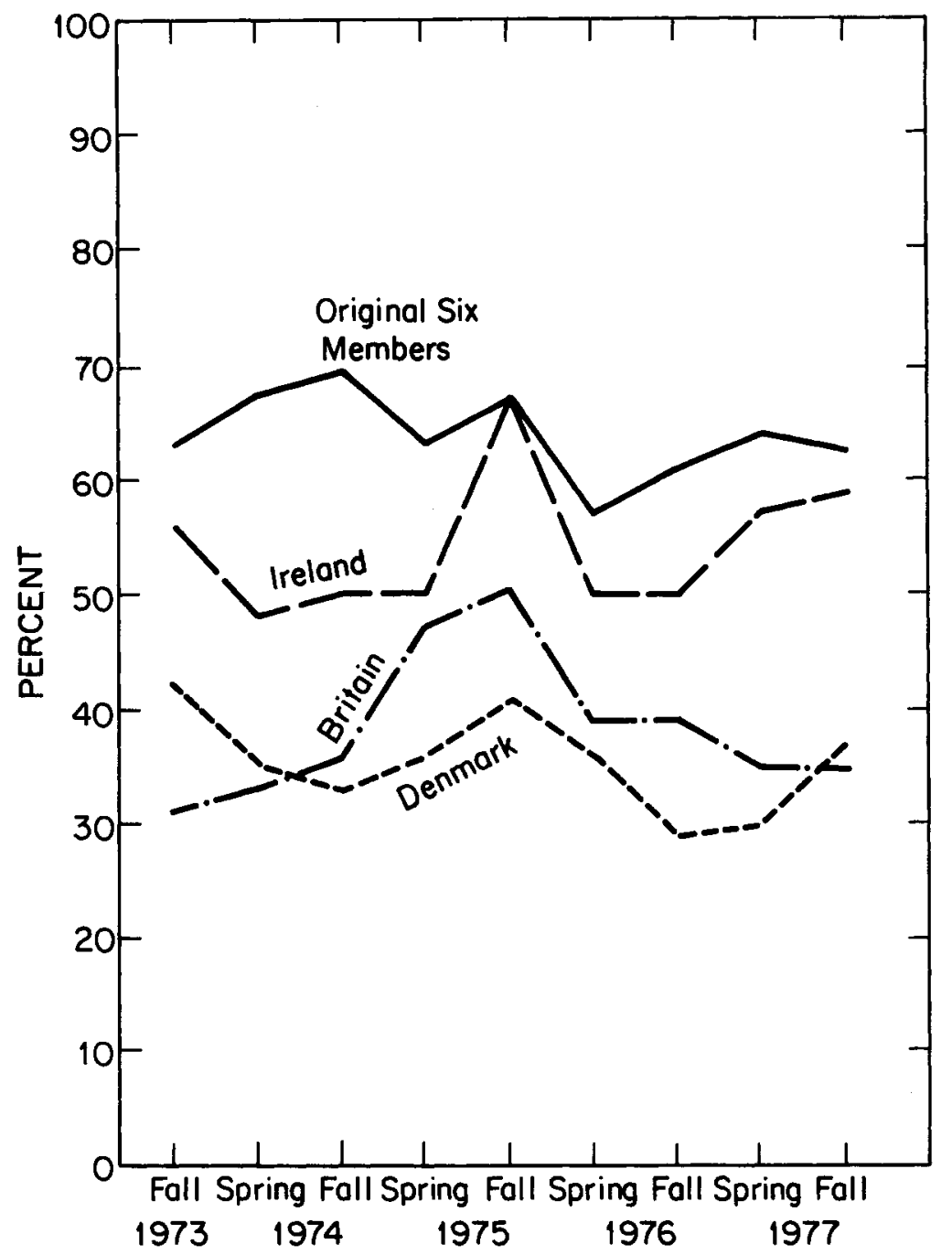

income was low by comparison with the rest of the European Community, and her unemployment level relatively high, but both of these things have been true of Ireland for decades. Presumably, it is changes from one's accustomed condition that influence public appraisals of the benefits of member- ship in the Community. In terms of recent change, Ireland fared relatively well. Her Index of Industrial Production showed only a modest decline by 1975 , and made an exceptionally strong recovery thereafter, standing far above her 1973 level in 1977.

If there is, indeed, a lag of a year 
FIGURE 3

industrial Production Rates in European Community Countries, 1973-1977 (SEASONALLY ADJUSTED, $1970=100$ ).

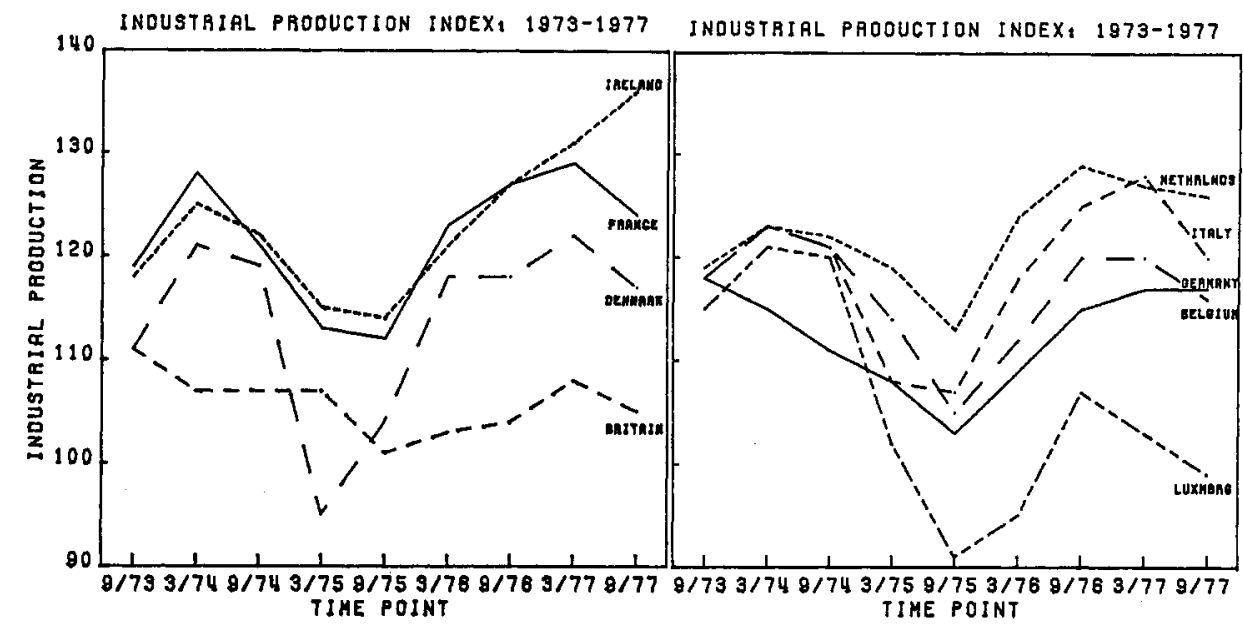

or so between changes in industrial production and changes in mass attitudes toward the Community, the next surveys should show a further rise in favorable appraisals of Common Market membership in Ireland and several other European Community countries. The existence of such a lag seems entirely plausible: one would expect to find some such delay, since the consequences of changing rates of production do not immediately impinge upon the general public, and there might well be some further delay before the public began to attribute these effects to any given cause.

The regression of our attitudinal variable on a given nation's index of industrial production one year before the given survey yields a correlation of $.253 .^{7}$ This lag provides our best fit: the correlations

7. For these regression analyses, evaluations of membership were coded as follows: $\operatorname{Bad}=1$, Neither $=2$. Good $=3$. The mean score for a given nation at a given point in time was the input to our aggregate data set. Missing data were excluded from calculations of the mean scores. with the index at earlier points in time yield lower values and the correlation with the index at the time of the survey is only .194. Though a correlation of .253 is scarcely overwhelming, it is significant at better than the .05 level when dealing with 81 data points, as we are here. Public evaluations of membership in the Community seem linked with economic growth or decline.

Can we explain more of the variance in attitudes by utilizing additional economic indicators? Yes. The best such measure, for present purposes, seems to be an indicator of inflation. Figure 4 shows the Consumer Price Indices for the nine European Community countries from 1973 to 1977 . Since these indices show a steady upward trend while our attitudinal measure does not, it is evident that we need to use the change in this index, during some specified period preceding a given survey, rather than the index itself, as a predictor of attitudes. Empirically, our best fit proves to be the rise in a nation's Consumer Price Index during the two years 
FIGURE 4

INFLATION RATES IN European COMMUNITY COUNTRIES, 1973-1977 $(1970=100)$.

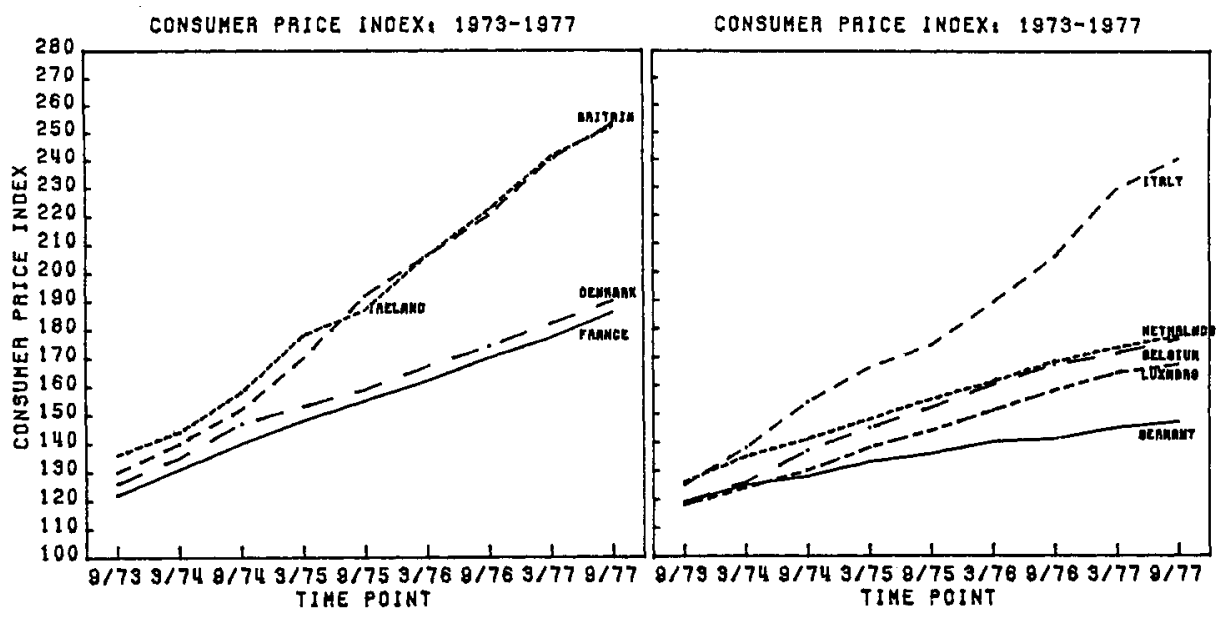

preceding the given survey. The lag involved here is longer, in a sense, than that connected with the Index of Industrial Production. This fact is somewhat surprising: the average consumer buys things almost every day. One might expect that he or she would become aware of inflation almost immediately. This may be true, but apparently it takes the public a certain period of time to connect inflation with EEC membership. Once this connection is made, however, its impact is slightly stronger than that associated with rising or falling rates of industrial production: our indicator of inflation shows a -.268 correlation with assessments of membership in the Common Market. The negative polarity, of course, indicates that relatively high rates of inflation are linked with negative assessments of membership.

Utilizing our indicators of both inflation and industrial production in the regression equation, we obtain a multiple correlation of .376 . Additional economic indicators (including measures of the change in unemployment rates) increase the amount of variance explained only very slightly; but our results do seem to indicate that economic conditions have a significant impact on public appraisals of membership in the E.E.C. These results support the idea that favorable outputs tend to enhance support for membership in a political community, while unfavorable ones have the opposite effect-but only in a loose way. It is unclear whether these "outputs" really come from the political system in question: the recession and inflation of the 1970's and their subsequent abatement were worldwide phenomena that probably were affected only marginally by any actions taken by the European Community institutions. However, the publics concerned here did seem to attribute prevailing economic conditions to their membership in the European Community, to some extent, and if they did, it is a significant fact. Given the relatively low rates of economic growth and high rates of inflation that were present most of the time 
since 1973, the net result was a slight decline in favorable assessments. But it is important to distinguish between long-term effects of membership and the impact of immediate economic conditions.

As we noted above, the publics of the original six member nations retained a relatively favorable view of membership throughout this period. Long-term factors - perhaps a reservoir of diffuse support built up during the pre-1973 era-were eroded only slightly. Let us put this statement into quantitative terms. We constructed a dummy variable based on whether a given nation joined the Community in 1958 or in 1973. Its correlation with our dependent variable is .896: this variable alone explains considerably more of the variance in attitudes than any available economic indicator or any combination of them. It seems unlikely that anything would greatly affect a correlation of this size. And, when this variable is used together with the economic indicators described above, in a multiple regression, neither the partial correlation (.863) nor the multiple correlation (.892) differ much from the zero-order correlation. It is impossible to prove, with the present data base, that the publics of the six make relatively positive evaluations of membership because they have been members for a relatively long time: it is conceivable (though it seems unlikely) that we are dealing with some cultural predisposition that just happens to be much more prevalent in the six than in the three. But the results of these analyses do clearly demonstrate the preponderance of long-term effects over those of the current economic environment, at least as measured by these standard economic indicators.
The economic context is important. Nation-specific effects, apparently linked with long-term membership, are even more important.

\section{The EMERGence of a SENSE of COMMUNITY SOLIDARITY}

Public evaluations of EEC membership remained static or declined slightly from 1973 to 1977 , for reasons that seem related to the troubled economic conditions of that period. Those publics that were already strongly favorable to membership in 1973 remained relatively favorable, for the most part, while those that had recently entered had become only slightly more favorable or even a little less so by 1977 .

We have dealt with only one aspect of public attitudes toward the Community, however. Assuredly it is a crucial one, for if a people conclude that their membership in a given political community is no longer a good thing, the next step might well be to leave it. Still, the appraisal of membership as measured here does not tell the whole story. The question we have been dealing with is framed in a way that tends to evoke an assessment of the utilization aspects of membership: one would expect such assessments to reflect the current economic context to a significant degree. Let us examine a less utilitarian, more affective aspect of mass attitudes toward the Community.

At three points in time, representative samples of the nine European Community publics have been asked: "If one of the countries of the Common Market (European Community) finds itself in major economic difficulties, do you feel that the other countries, including (your country), should help it or not?" This 
question evokes responses concerning what should be done, not simply an appraisal of what has happened. The responses obtained from each public in 1973 appear in Table 3. By comparison with appraisals of the benefits of EEC membership, the levels of support for Community solidarity were strikingly high. There was a good deal more opposition in Denmark and the United Kingdom than in any of the original six member nations, but the principle of aiding other European Community countries in time of need was endorsed by strong majorities in all nine countries.

In a sense, these high levels of support for European Community solidarity are not surprising. The Danish and Irish publics had just voted to join the Community in 1972 , in national referenda that evoked intense and widespread discussion of the choice being made. There would seem to be little sense in joining, unless one were committed to a certain degree of solidarity. The British electorate had not yet been consulted on the subject, but their representatives in Parliament had debated extensively and finally voted in favor of joining the European Community by a conclusive majority: cues from the political elites tended to encourage a sense of solidarity - which was endorsed by a 2:1 majority among the British public. The ratio was almost 7:1 in the Community as a whole, however. These high levels of support for Community solidarity were expressed during the first year of membership for the three new countries. The very fact that the Community had just been expanded, after years of debate and difficult negotiations, may have given the Community a psychological boost that would not necessarily last; all of this took place before the Arab oil embargo of October, 1973 and the sharp economic decline of 1974 and 1975. Would this remarkably high level of public support for economic solidarity collapse in the fact of real, rather than hypothetical, economic difficulties? For the Community as a whole, the answer is a clear-cut "No."

Table 4 shows the levels of support for Community solidarity at each of the three points in time when this question was asked. The same data are summarized in graphic form in Figure 5, with results from the original six members combined in an average weighted according to national populations. The overall pattern is not one of collapse, but of upward convergence. Among the original six, sup-

TABLE 3

Sense of European Community Solidarity, Fall, 1973: If a Member Country is in Major ECONOMIC DIFFICULTIES, SHOULD THE OTHER COUNTRIES - INCLUDING YOUR OWN-HELP IT? (RESPONSES FROM SURVEY IN LATE SEPTEMBER AND EARLY OCTOBER, 1973)

\begin{tabular}{lccrrrrrrrr}
\hline \hline & Fanance & Belg. & Neth. & $\begin{array}{c}\text { Ger- } \\
\text { Many }\end{array}$ & Italy & Lux. & Den. & Ife. & UK & $\begin{array}{c}\text { European } \\
\text { Community }\end{array}$ \\
\hline Should Help It: & $78 \%$ & 78 & 79 & 77 & 88 & 87 & 62 & 80 & 59 & 76 \\
Should Not Help It: & 9 & 9 & 9 & 7 & 2 & 8 & 25 & 10 & 28 & 11 \\
Don't Know & 13 & 13 & 12 & 16 & 10 & 5 & 13 & 10 & 13 & 13 \\
\hline
\end{tabular}

\footnotetext{
* Weighted in proportion to national populations; unweighted $N=13,484$
} 
TABLE 4

SENSE of EUROPEAN COMMUNITY SOLIDARITY, 1973-1975 (PERCENTAge Saying TheIR Country Should Help ANOTHER E.C. NATION IN DifFICULTY)

\begin{tabular}{lccc}
\hline \hline & $\begin{array}{c}\text { FALL } \\
1973\end{array}$ & $\begin{array}{c}\text { FALL } \\
1976\end{array}$ & $\begin{array}{c}\text { FALL } \\
1977\end{array}$ \\
\hline France & 78 & 75 & 76 \\
Belgium & 78 & 82 & 74 \\
Netherlands & 79 & 84 & 85 \\
Germany & 77 & 74 & 72 \\
Italy & 88 & 95 & 92 \\
Luxembourg & 87 & 86 & 83 \\
Denmark & 62 & 68 & 75 \\
Ireland & 80 & 83 & 83 \\
UK & 59 & 77 & 75 \\
\hline
\end{tabular}

port for economic solidarity remained at very high levels, with little overall change. And among the three new member publics, support for Community solidarity showed a substantial rise. Ireland, which already ranked high in 1973, rose to a level slightly higher than the average for the original six; while the British and Danish publics showed substantial gains that left them only slightly below the six.

It seems significant that the German level of support showed a moderate but appreciable decline, while the Italian level showed a comparable rise-during this period Germany was called upon to provide actual economic aid to Italy, and did provide it. Nevertheless, even in Germany the proponents of economic solidarity prevailed over its opponents by more than $7: 1$ in November 1977; and for the Community as a whole there was an upward shift. Its magnitude, weighted according to the size of national populations, is a net gain of three percentage points from 1973 to 1977 . This is a modest figure, to be sure, but we tend to run into ceiling effects. In the case of the original six, the percentages favoring soli- darity simply cannot rise very much farther; outright opposition was already very low in 1973 and a certain proportion of nonresponse seems inevitable in any national public opinion survey. The gain was concentrated almost entirely in the three new member nations. The fact that there has been a pattern of upward convergence, with the new members catching up with the original six, seems more significant than the absolute size of the overall upward movement.

Despite the uncertain economic climate that has prevailed since expansion of the European Community in 1973, there have been important gains in the prevalence of a sense of Community solidarity. As was suggested earlier, the sheer passage of time under common supranational institutions may tend to instill the habit of viewing things from a broader perspective than that of the nation-state, even in the absence of material rewards. The Fall 1977 survey provides another piece of evidence that helps explain the surprising fact that a sense of Community solidarity became more widespread from 1973 to 1977 , while public appraisals of the benefits of membership were stagnant or showed a tendency to decline. In addition to asking each respondent whether he or she felt that membership was a good or bad thing, they were asked, "And do you think that (your country's) membership in the Common Market is a good thing, a bad thing or neither in the light of (your country's) future in the next ten or fifteen years?" Pluralities (and in most cases, clear majorities) of the publics of all nine countries felt that their country's membership would prove to be a good thing in ten or fifteen years time. For example, 
while only 35 percent of the British public felt that British membership was a good thing in the Fall of 1977,48 percent felt that it would be a good thing in the long run.

It is, of course, impossible to say what actually will have happened by 1988 or 1993 . But the difference between the two responses suggests that, while the various publics were quite aware of the troubled circumstances of the recent past, they had not lost hope for the Community's future.

\section{Direct EleCtions to EUROPEAN PARLIAMENT}

There is additional evidence of a growing sense of European Community solidarity. It concerns the forthcoming direct elections to the European Parliament. Public support for holding such elections has, itself, shown impressive growth. Earlier a matter of controversy, particularly in the new member nations, by 1977 a consensus had emerged throughout the Community in favor of them. Over time, the idea of holding such elections has evolved from a hypothetical proposal to a coming reality, which has probably encouraged public acceptance. It has also required certain changes in the wording of the survey items designed to measure public support or opposition to the European elections.

In 1970 , representative samples of the publics of the six countries that were then members were asked: "Are you for or against the election of a European parliament by popular vote of all the citizens of the member states of the European Community?" A similar question was asked in Great Britain, but since it was not then a member of the Community, it was placed in the context of hypothetical British entry. The question was repeated in 1973, except that this time four categories of response were offered: "completely in favor," "favor on the whole," "disagree in general," and "disagree completely." By Spring, 1975, a concrete proposal was being discussed to hold direct elections to the European Parliament in 1978, and the question was worded: "One of the main proposals is to elect a European Parliament in May 1978, by a popular vote of all the citizens in the member states of the European Community (Common Market). Are you, yourself, for or against this proposal? How strongly do you feel about it?" The same four response categories were offered as in 1973; and this question was repeated in each survey through May 1976. By Fall 1976, agreement had been reached on the goal of holding direct elections in May 1978 (although important details remained to be worked out that, in fact, delayed the elections until Spring 1979). Accordingly, in Fall 1976 the question was phrased: "The governments of the member countries of the Common Market have reached agreement to hold the first elections to the European Parliament by universal suffrage, that is, by direct vote of all citizens, in May 1978. Are you, yourself, for or against this particular election?"

The same four response categories were offered as stated above. In Spring and Fall 1977, the introductory wording was simplified to read: "In 1978, elections for the European Parliament are planned in every country of the Common Market including (your country). Everybody will be entitled to vote. Are you, yourself, for or against this particular election?" Again, four 
FIGURE 5

Sense of European Solidarity, 1973-1977. Percentage Saying That Their Country SHOULD HELP ANOTHER EUROPEAN COUNTRY IN DIFFICULTY.

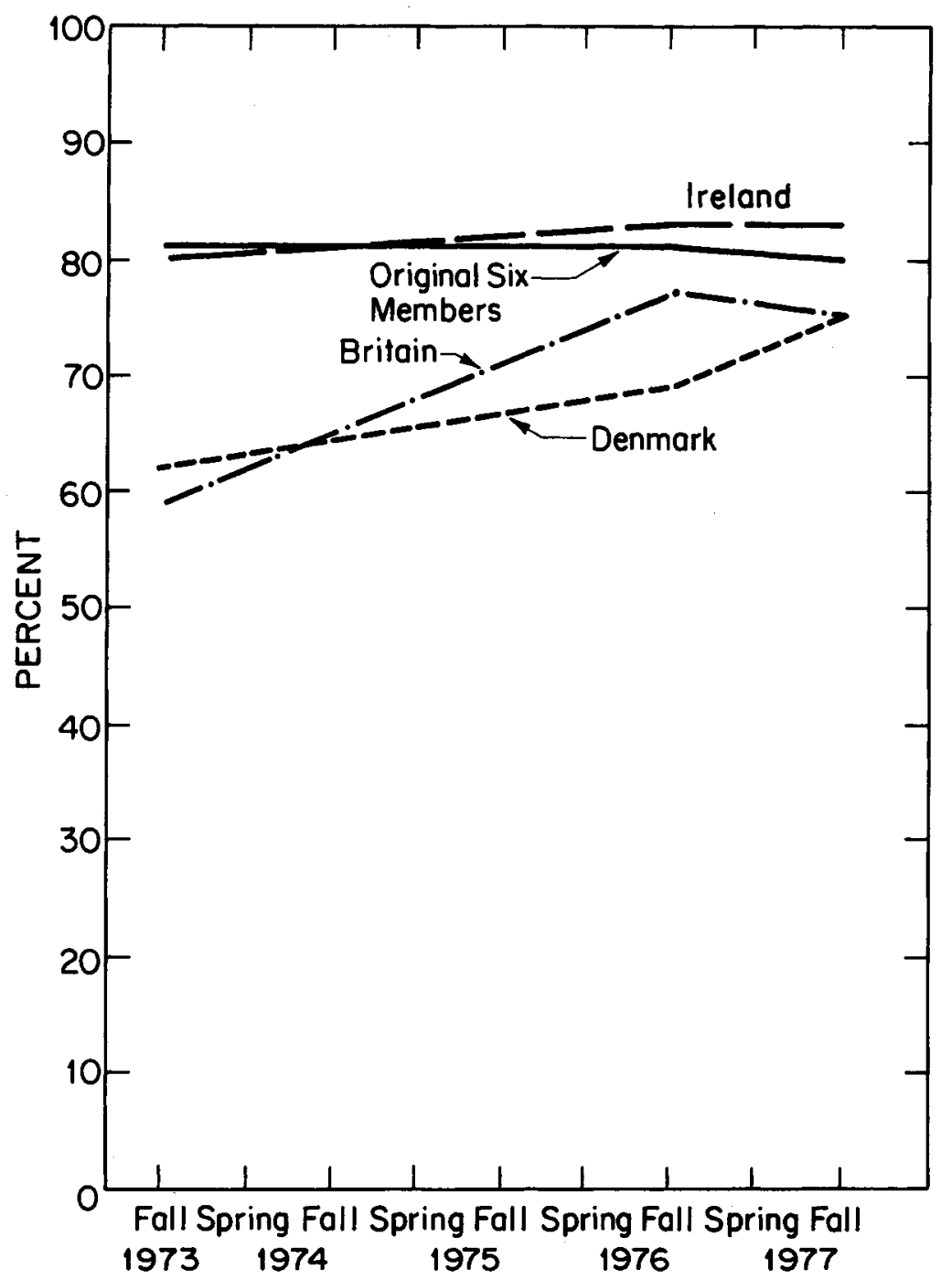

response categories were offered. approved by the respective governFigure 6 shows the changes over ments, support for a directly-elected time in the percentage completely European Parliament changed only favorable, or to some extent favor- gradually in the original six memable, to a directly-elected European Parliament. Despite the various changes in wording of the question, and the shift from a distant possibility to a measure that had been ber countries, rising from a weighted average of 60 percent favorable in 1970 , to 74 percent favorable in Fall 1977. Changes among the publics of the three new member coun- 
FIGURE 6

Percentage "for" a Directly Elected European Parliament, 1970-1977.

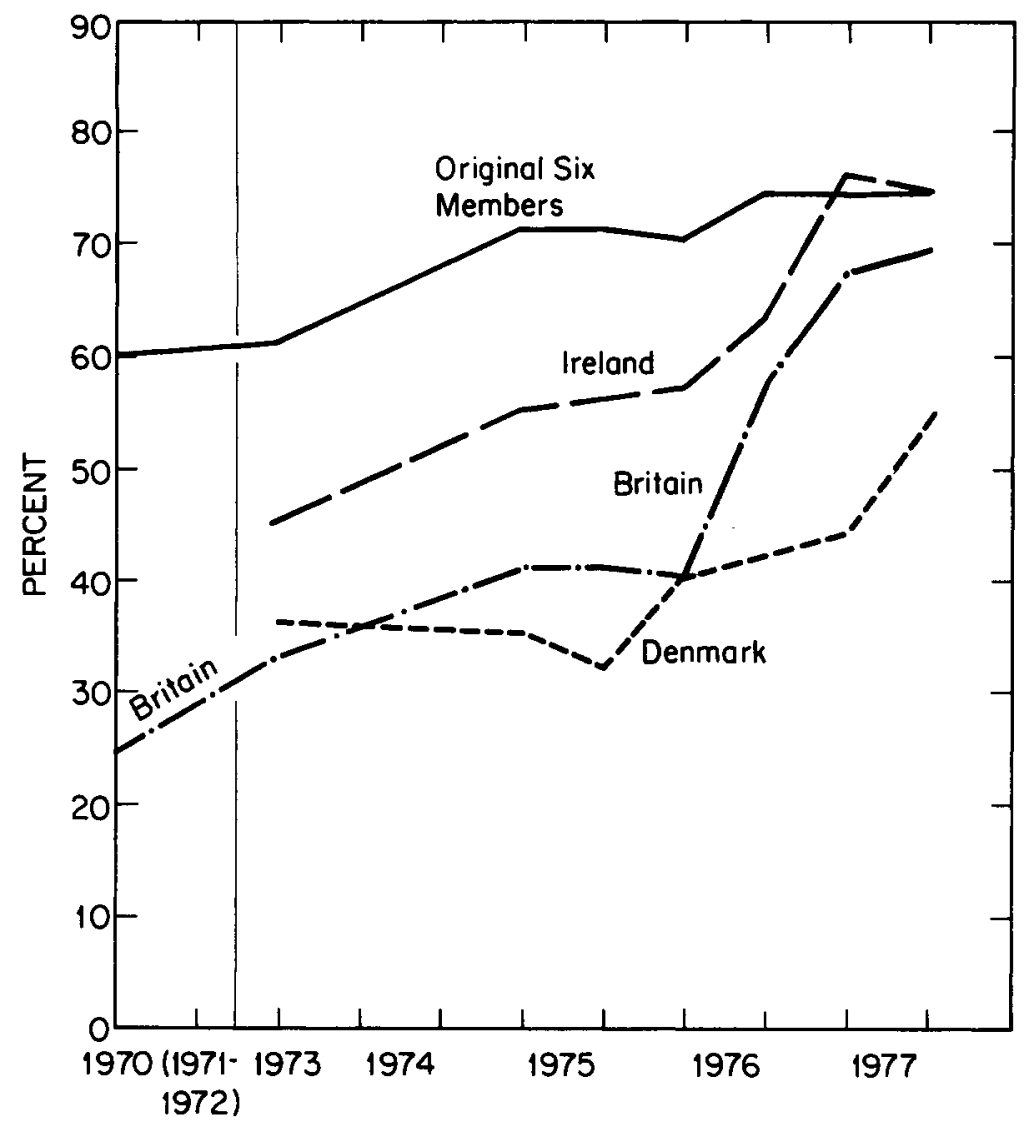

tries were dramatic by comparison. In 1970, only 25 percent of the British public were favorable, while a 55 percent majority were opposed to a directly elected European Parliament. By late 1977, support was voiced by 69 percent and opposition by only 18 percent. In our earliest Danish survey, nine months after Danish entry, only 36 percent were favorable while 43 percent were opposed. By 1977 these figures had shifted to 54 percent and 29 percent, respectively. In Ireland, a 45 percent plurality were already favorable to a directly elected European Parliament in 1973, but this figure rose to 74 percent in 1977 .
Once again, we find the phenomenon of upward convergence, with the three new member publics catching up with the original six, but here the evidence is far stronger than anything we have seen above. It seems likely that much of the change since 1975 is due to a process in which the publics became aware of, and influenced by, decisions made by national elites. But if this were the case, it illustrates forcefully the extent to which these publics can be mobilized in support of European institutions when their generally favorable predispositions are reinforced by positive action on the part of political leaders. 
The growth of public backing for direct elections to the European Parliament is impressive, but it is probably a relatively soft indicator of a sense of European solidarity. One might favor such elections in the belief that the European Parliament will remain unimportant; or because one sees it as a forum for the defense of national interests. The 1977 surveys included a question that enables us to examine the latter possibility. It is also a relatively "difficult" question that helps provide an indication of the distribution of hard-core Europeans, because it explicitly pits the national interest against that of the Community as a whole. The item is: "Which of the following attitudes would you expect a (British, French, etc.) member of the European Parliament to have?

- He should support things that are good for Europe as a whole, even if they are not always good for (my country) at the time.

- He should support the interests of (my country) all the time whether or not they are good for Europe as a whole.

The responses to this item in Fall 1977 appear in Table 5.

The proportion according priority to the interest of Europe as a whole above the national interest is far smaller than the proportion favoring a directly-elected European Parliament, as one would expect. In the three new member countries the national interest is clearly preponderant over that of the Community. In Belgium, the two are in nearly even balance. But in the remaining five of the original six member countries - and in the Community as a whole-the predominant attitude is to feel that one's representative in the European Parliament should support measures that are good for Europe as a whole, even if they run counter to the immediate national interest.

This question has not been asked over a sufficient period of years to enable us to draw any conclusions about long-term trends. The fact that the publics of the older member countries are substantially more likely to give priority to European interests suggests that the formation of a European outlook is something that develops rather slowly. It does not, however, necessarily indicate the direction in which the three newer publics are moving.

In a sense, this item provides a test of whether an individual is prepared to become a citizen of Europe. And the results indicate that Europeans do exist. They are outnumbered by those who are citizens of a given country first and foremost, among the three newer members of the Community. But among those publics that had experienced almost twenty years of membership in the Community by Fall 1977, the Europeans seemed to comprise a majority.

\section{INDIVIDUAL-LEVEL DIFFERENCES IN ASSESSMENT OF MEMBERSHIP AND A SENSE OF CoMMUNITY SOLIDARITY}

Up to this point we have focused entirely on variations in public attitudes across nations and across time. Nations are not monolithic, however; within each country, one finds substantial differences in support for European integration between people of different sex, age, occupation, political loyalties and educational levels. In order to understand changes over time in the support levels of given nationalities, we must analyze these individuallevel differences as well as the political and economic environment 
of given nations at given times. For example, the upward convergence of the French and Italian publics with the other publics of the original six-member European Community can be attributed, in large part, to the conversion of the communist electorates of these countries from hostile to favorable orientations toward integration. ${ }^{8}$

Among those individual-level characteristics that show substantial associations with support for European integration, education is probably the most pervasive: the highlyeducated are consistently more favorable than the less-educated. This finding emerges from virtually every nationwide survey that has ever been conducted on the subject. The fact itself is clear and unmistakable. But it can be interpreted in a variety of ways.

On one hand, it could be attributed to the fact that the more educated tend to have higher incomes and more desirable jobs than the less educated. Accordingly, the argument might plausibly be developed that education is linked with support for integration because the more educated respondents tend to be of higher social class level; European integration benefits the upper and middle classes more than the working class; thus the fact that the more educated are relatively favorable to integration is simply an expression of social class interest. ${ }^{9}$ Carried a bit farther, one

8. See Inglehart, The Silent Revolution, Chapter 12; and Robert D. Putnam, "Interdependence and the Italian Communists," International Organization, 32, 2 (Spring, 1978), forthcoming.

9. In practice, it is difficult to demonstrate that integration benefits the middle class more than the working class. The former unquestionably do have higher incomes and social status, but there is very little evidence that these differences would be smaller if could argue that support for European integration is inherently a Right-wing political position, while opposition to integration is the natural stance of the Left. In support of this argument one could marshal evidence that the electorates of the Left tend to be less favorable to integration than those of the Right. This is frequently, but by no means universally truebut one might save the hypothesis by arguing that in some countries, the electorates of the Left have fallen prey to delusions. The implication of this general interpretation is that the future growth or decline of mass support for European integration depends essentially on whether the Left or the Right ultimately triumphs.

The foregoing interpretation makes the assumption that the more educated are relatively pro-European because they tend to come from higher social class backgrounds. But education is a complex variable that taps many things. It is indeed an indicator of one's social class. It is also an indicator of the presence or absence of certain cognitive skills, for the more educated tend to know more, and are more accustomed to dealing with abstractions and remote objects than the less educated. Finally, education is an indicator of one's social milieu: the more educated tend to move in different circles, read or view different media, and become exposed to different influences from the less educated. It may be true that the

the Community did not exist. An alternative version of the argument might therefore be that, regardless of whether they actually do benefit more, middle class respondents are more likely to think that they do and this explains their higher levels of support for integration. 
TABLE 5

\section{European Community Solidarity: Should Priority be Given to Your Country's NATIONAL INTERESTS OR TO THOSE OF EUROPE AS A WHOLE? (RESPONSES TO FALL, 1977 SURVEY)}

\begin{tabular}{|c|c|c|c|c|c|c|c|c|c|c|}
\hline $\begin{array}{l}\text { A (BRITISH, FAENCH, ETC.) MEMBER OF THE } \\
\text { EUROPEAN PARLIAMENT SHOULD: }\end{array}$ & FAANCE & Belg. & NETH. & Ger. & ITALY & Lux. & DEN. & IRE. & uK & $\begin{array}{l}\text { EURO- } \\
\text { PEAN } \\
\text { COM- } \\
\text { MUNITY* }\end{array}$ \\
\hline $\begin{array}{l}\text { Support things that are good } \\
\text { for Europe as a whole, even if } \\
\text { they are not always good for } \\
\text { (my country) at the time }\end{array}$ & $48 \%$ & 39 & 65 & 49 & 54 & 48 & 36 & 35 & 42 & 48 \\
\hline $\begin{array}{l}\text { Support the interests of (my } \\
\text { country) whether or not they } \\
\text { are good for Europe as a whole }\end{array}$ & 40 & 41 & 27 & 36 & 39 & 43 & 52 & 58 & 52 & 41 \\
\hline Don't Know & 12 & 20 & 8 & 15 & 7 & 9 & 12 & 7 & 6 & 11 \\
\hline
\end{tabular}

* Weighted in proportion to national populations.

more educated are relatively proEuropean simply because this is the best way to pursue a distinctive class interest. But it could work the other way around: it might be that any observed social class differences in levels of support for European integration result from the fact that middle class respondents have, on the whole, received more education than working class respondents.

Let us compare the relative strengths of the relationships between support for European integration and the respondent's educational level on one hand, and the occupation of the head of the respondent's household, on the other. Table 6 shows the percentages making positive appraisals of European Community membership by education and occupation in the European Community as a whole, as of Fall 1977. Though there is some cross-national variation in the strength of these relationships, these figures are reasonably representative of the pattern that is found in each of the nine member nations (though not, of course, of the absolute levels). They are also fairly typical of those found at other points in time, though it seems worth mentioning that both of these relationships were somewhat stronger in 1977 than they were in 1973.

The first thing that we might note is the fact that respondents in households headed by manual workers do, indeed, make less favorable appraisals of EEC membership than those in households headed by a person with a nonmanual occupation. The impression that these data convey, however, is scarcely one of social class polarization: a majority of the respondents in both manual and nonmanual households made favorable appraisals; there is simply a difference in degree and the difference is not overwhelming. Furthermore, when we compare the responses of all four broad occupational categories, there is no monotonic relationship between income and the proportion making favorable appraisals: those from farm households have the lowest mean family income but they prove to be fully as favorable as our highest income group, those from nonmanual house- 
TABLE 6

\section{Appraisal of European Community MEMBERSHIP BY EDUCATION AND BY Occupation, Head of House- hold (Percentage Saying THAT THEIR COUNTAY'S MEMBERSHIP IS A GOOD THING)}

\section{By Education}

$\begin{array}{lll}\text { Respondent left school at: } & \\ \text { Age } 15 \text { or younger } & 54 \% & (4179) \\ \text { Ages } 16-18 \text { years } & 63 & (2308) \\ \text { Age } 19 \text { or older } & 73 & (1885) \\ \text { Eta }=.154 & & \end{array}$

\section{By Occupation, Head of Household}

$\begin{array}{lll}\text { Farmer } & 68 \% & (291) \\ \text { Manual worker } & 53 & (2421) \\ \text { Nonmanual } & 68 & (3454) \\ \text { Inactive } & 57 & (2204) \\ \quad \text { Eta }=.136 & & \end{array}$

* Fall, 1977 nine-nation survey, weighted according to population. Weighted N's are shown in this and subsequent tables.

holds. Finally, the apparent impact of education on one's attitude proves to be stronger than the apparent impact of one's occupation. A simple comparison of the size of the percentage differences between the various groups suggests that this is the case, and the relative size of the Eta coefficients confirms it. When we enter both variables into a Multiple Classification Analysis that adjusts for the effects of nationality, income, age, and political party preferences, as well as the effects of education and occupation on each other, we obtain Beta coefficients of .090 and .045 for education and occupation, respectively. Education proves to be a more powerful predictor of attitudes than does occupation. In other words, our data give more support to the hypothesis that middle class respondents are relatively favorable to European integration because they tend to have relatively high levels of education than to the converse hypothesis.

But this still leaves unanswered the question of why the more educated tend to be relatively favorable. Could it be due to the influence of distinctive political party preferences? In general, the more educated are more likely to support relatively conservative political parties than the less educated; and, as we have noted, in most (though not all) of the European Community countries the parties of the Right give more support to European integration than those of the Left. Could this be a cause of spurious correlation? Again, the answer seems to be no. Table 7 shows the distribution of favorable appraisals of EEC membership among those who support political parties of the Left and Right respectively, at four points in time in the Community as a whole.

The electorates of the Left consistently make less favorable assessments of membership than do those of the Right, although the gap seems to have narrowed since 1973, but the percentage differences found here are even smaller than those associated with manual versus nonmanual occupations. There are major cross-national differences in the explanatory power of this variable, which we will touch on later. On the whole, the partisan differences are modest (the Eta coefficient for this variable in Fall 1977 was only .064). This fact suggests, and more detailed statistical analysis confirms, that the attitudinal differences by education and occupation could be attributed to differential political party preferences to only a limited extent. The fact remains that the more educated are consistently more favorable to Euro- 
TABLE 7

APPRAISAL OF EUROPEAN COMMUNITY MEMBERSHIP BY POLITICAL PARTY Preference: 1973-1977 (PerCENTAGE SAYING THAT THEIR COUNTRY'S MEMBERSHIP IS A GOOD THING)

\begin{tabular}{lllll}
\hline \hline $\begin{array}{l}\text { RESPONDENT } \\
\text { SuPPORTS } \\
\text { A PARTY }\end{array}$ & FALL & FALL & FALL & FALL \\
OF THE: & 1973 & 1975 & 1976 & 1977 \\
\hline Left & $60 \%$ & 57 & 55 & 58 \\
Right & 73 & 69 & 65 & 65 \\
\hline
\end{tabular}

pean integration than the rest of their compatriots, and this is one of the most important attitudinal cleavages within the respective countries. Why?

\section{Two Analytical Hypotheses}

Earlier analyses have suggested two distinct types of underlying causes. They might be described as the "Cognitive Mobilization" hypothesis and the "Materialist/ Post-Materialist" hypothesis, respectively. Both hypotheses have been developed in considerable detail in previously published work. We will provide only a brief summary of them here. ${ }^{10}$

The Cognitive Mobilization hypothesis argues that the rising educational levels of recent decades, coupled with the growing availability of information about things happening in distant places, is conducive to an increasingly cosmopoli-

10. For a fuller discussion of "Cognitive Mobilization" see Inglehart, "Cognitive Mobilization and European Identity," Comparative Politics 3, 1 (October 1970) pp. 45-70; the Materialist/Post-Materialist hypothesis was first developed in Inglehart, "Changing Value Priorities and European Integration," Journal of Common Market Studies 10, 1 (September 1971) pp. 1-36. Both themes have been explored further in Inglehart, The Silent Revolution, Chaps. 2, 11, 12. tan outlook on the part of Western publics. The ability to handle abstractions, to process information about remote and complex entities (such as the European Community) lies at the heart of the Cognitive Mobilization process, and formal education tends to increase these skills. The illiterate peasant tends to be a parochial whose horizons are limited to the village or rural area in which he lives. ${ }^{11} \mathrm{His}$ involvement in politics tends to be based on personal loyalties and word-of-mouth communications. The relatively well-educated publics of contemporary Western Europe are far better equipped to understand and take part in politics at the national level. To a greater degree than was true in the past, they are able to process information about what is happening in Europe as a whole, and the penetration of electronic communications media makes such information readily available. One consequence is that these publics are relatively likely to know about and discuss European politics and to view things from a European perspective. For

11. The classic empirically based study of parochial versus cosmopolitan worldviews among mass publics is that of Daniel Lerner, The Passing of Traditional Society (New York: Free Press, 1958). In their seminal study, The Civic Culture (Princeton: Princeton University Press, 1963), Gabriel Almond and Sidney Verba document the importance of formal education in promoting a sense of "subjective political competence" and a participant role in politics. We view Cognitive Mobilization as an extension of the social mobilization process that continues within the individual after the external landmarks of social mobilization (such as urbanization, universal suffrage, industrialization and compulsory education) have been completed. See Karl W. Deutsch, "Social Mobilization and Political Development," American Political Science Review 55, 2 (September, 1961) pp. 493-514. 
many (especially among the publics of the original six member countries) the European Community has become a familiar object rather than something strange and threatening.

The Materialist/Post-Materialist hypothesis holds that people have a variety of needs, ranging from needs for subsistence and physical safety, to needs for belonging, solidarity, esteem and realization of one's intellectual and esthetic potential. Though all of these things are valued, people give priority in their values and behavior to those needs that are in relatively short supply.

Throughout most of recorded history, most people have been preoccupied by the struggle for material survival. But the unprecedented prosperity of western countries in recent decades has led to the emergence of substantial numbers of Post-Materialists - people who give top priority to the needs for belonging and self-realization. A Materialist value type (that gives top priority to the sustenance and safety needs) remains far more numerous, however.

One's basic value priorities tend to crystalize during pre-adult years and change relatively little thereafter. Accordingly, one's relative emphasis on survival or higher-order needs is a relatively fixed characteristic and not simply a response to the immediate environment. In a given setting, the Materialist value type tends to focus mainly on the pursuit of economic and physical security, while the Post-Materialist type places more emphasis on belonging and intellectual pursuits. One consequence is that, quite apart from their relative levels of Cognitive Mobilization, the Post-Materialists are more likely to take an interest in remote and abstract
causes-European integration being one of many possibilities - and to place relatively heavy emphasis on a sense of European solidarity (as one of numerous possible ways to satisfy the need for belonging).

The two hypotheses that we have just sketched out imply that relatively well-educated and economically-secure groups will tend to be relatively favorable to European integration, other things being equal. This is not an iron law of universal determinism, merely a probable relationship. It is possible, for example, that a Post-Materialist might seek to attain a sense of belonging through involvement in some cause aimed at political disintegration rather than integration: Belgium's Flemish separatists seem to constitute a case in point. Nevertheless, those with Post-Materialist value priorities have a relatively high potential for mobilization in support of such causes as European integration; and the higher their level of Cognitive Mobilization, the greater their potential for involvement.

The implications for European integration of these two hypotheses were subjected to empirical tests based on survey data from 1970 and 1973, and the results generally support the interpretation just given. ${ }^{12}$

12. For a detailed account of the operationalization and testing of these hypotheses, see the sources cited in $n$. 11. Very briefly, we hypothesized that those who had spent their formative years in economic and physical security would be most likely to have PostMaterialist values. Accordingly, the indicator of value type used in this article is based on responses to the following questions:

If you had to choose among the following things, which are the two that seem most desirable to you?"

- Maintaining order in the nation

- Giving the people more say in important political decisions 
- Fighting rising prices

- Protecting freedom of speech.

The first item, Order, was designed to tap concerns for physical safety; the third item, rising prices, was designed to tap a concern for economic stability. The two other items reflect nonmaterial, expressive concerns. On the basis of their two choices, our respondents thus fell into three categories: the Materialists (those who chose the first and third items together); the Post-Materialists (those who chose the second and fourth items together); and the Mixed types (those choosing any of the four remaining combinations). While this simple 4-item battery provides a parsimonious and fairly effective indicator of value priorities, a 12-item battery has been developed that is more accurate and reliable. It is more difficult to measure skills than attitudes in a public opinion survey. For practical reasons, our measures of cognitive level are indirect. The Cognitive Mobilization indicator used here is based on responses to two questions that have become standard items in the European Community surveys. They are:

When you get together with your friends, would you say that you discuss political matters frequently, occasionally, or never?

When you, yourself, hold a strong opinion, do you ever find yourself persuading your friends, relatives or fellow workers to share your views? (if yes): Does this happen often, from time to time or rarely?

Our reasoning in using these items as indicators of skills (which clearly, they do not measure directly) is that those who know and understand something about political life are most likely to discuss it; and that those most skilled in argumentation are most apt to attempt to persuade others to adopt their opinions. Needless to say, this is not always true. But overall, the "Mobilized" responses to these items show strong positive correlations with one's level of political information, sense of political competence and education, as is demonstrated in Inglehart, The Silent Revolution, Chapter 11. We dichotomized between relatively "High" and "Low" levels of Cognitive Mobilization by classing as "high" those who discuss politics "frequently" or "occasionally," and persuaded other people "often" or "from time to time." Those who discussed politics "frequently" were ranked "high" even if they didn't persuade others to accept their views. The remaining respondents were classed as "Low" on Cognitive Mobilization. Obviously, this is a generous definition of "High" levels of Cognitive Mobilization-
One wonders, however, how well the empirical relationships observed in the early 1970's would hold up in the changed socioeconomic environment of the late 1970's.

In order to examine the current relevance of mass publics' value priorities and cognitive skills to support for European integration, we set out to develop a typology that would enable us to measure the combined effects of the two variables. A typology seemed useful because, while the Post-Materialist type tends to rank high on Cognitive Mobilization, there is nothing that approaches a one-to-one relationship, empirically. Moreover, the effects of the two variables are not necessarily additive: they display some interesting interaction effects, as we will see below.

A series of typological analyses were carried out in order to examine the relative homogeneity of various groups in regard to values, levels of Cognitive Mobilization and certain related attitudes. ${ }^{13}$ The results of these analyses support the construction of a typology based on two sets of three groups: the six types consist of, on one hand, the Materialist, Post-Materialist and Mixed (or intermediate) value types among those with relatively low levels of Cognitive Mobilization; and the Materialist, Post-Materialist and Mixed value types among those respondents having relatively high levels of Cognitive Mobilization.

But in addition to these six groups,

but even by this liberal standard, the majority of the public fell into the "Low" category.

13. Much of the groundwork for the Political Orientation Typology used here was laid by Bruno Roche of the Institut Francais d'Opinion Publique, who carried out an initial series of typological analyses. The authors are indebted to $M$. Roche for his contributions. 
the typological analyses point to the existence of a seventh group, having such distinctive characteristics that it should be treated as a separate category in the typology. The respondents in this seventh group were identified by their responses to the question:

On this card are three basic kinds of attitudes toward the society in which we live. Please choose the one which best describes your own opinion:

1. The entire way our society is organized must be radically changed by revolutionary action.

2. Our society must be gradually changed by reforms.

3. Our present society must be valiantly defended against all subversive forces.

As shorthand terms one might refer to the three respective options as Revolution, Reform, and Reaction. In November 1977 the percentages choosing each option in the Community as a whole (weighted according to population) were 6 percent, 55 percent and 32 percent respectively-with 7 percent giving no answer.

While those who choose the first or Revolutionary option constituted only six percent of the European public, they are a particularly interesting and highly distinctive group. In regard to both value priorities and Cognitive Mobilization, there was considerably more difference between the Revolutionaries and the Reformists than between the Reformists and the Reactionaries or nonresponding groups. Specifically, the Revolutionaries have disproportionately high levels of political interest and activity in discussions; and a quite disproportionate tendency to be Post-Materialists. We hasten to emphasize that it would be a serious error to conclude that all Post-Materialists are potential
Revolutionaries. There is a Reformist majority among all three value types. But when we focus our attention on the two extremes of the Revolutionary-Reactionary continuum, we find striking differences according to value type. Among the Materialists, Reactionaries outnumber Revolutionaries by an overwhelming 10:1 ratio. Among the mixed value types Reactionaries outnumber Revolutionaries by $4: 1$. But among the Post-Materialist group, the ratio is approximately 1:1 - with Revolutionaries more numerous than Reactionaries. The Revolutionaries resemble the PostMaterialists in being considerably younger and better educated than the population at large. Furthermore, the two groups are similar in showing a decided preference for the political parties of the Left. But in other crucial respects they are dramatically different, as we will see shortly. Consequently, we constructed a Political Orientation Typology containing seven, rather than six groups, using the procedure shown in Figure 7.

Figure 7 shows the percentage of the European Community public (weighted according to population) falling into each of the seven types in Fall 1977. We replicated this procedure using data from the Fall 1976 surveys. The distribution of the respective types proved to be quite stable: in Fall 1977 six of the seven groups were within one percent of their Fall 1976 distributions. The seventh group - the Mobilized Materialists - increased from 12 percent of the total in 1976 to 14 percent in 1977. There was a shift toward Materialism from 1976 to 1977 , and it was concentrated among those ranking high on Cognitive Mobilization. The Non-Mobilized Materialists showed no gain. 


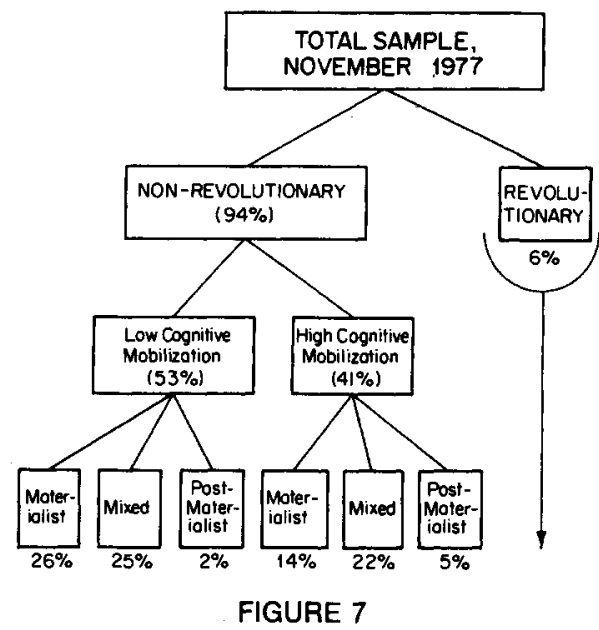

Construction of Political Orientation Typology. Percentages in each Category ARE BASED ON FALL, 1977 SURVEY.

Let us examine some of the politically relevant characteristics of the seven groups in our typology. A standard item in the European Community surveys is the question:

In political matters people often talk of 'the Left' and 'the Right.' How would you place your own views on this scale?" [The respondent is given a scale divided into ten boxes, running from Left to Right. At the left end of the card, the word "Left" appears and at the right end, the word "Right". The ten boxes are numbered from 1 to 10 and the respondent is asked to give the number of the position at which he would place himself. If he or she hesitates, he or she is asked to try again].

Table 8 shows the mean score on the Left-Right ideology scale for each of the seven groups in our typology. At a given level of Cognitive Mobilization, Materialists are substantially more likely to place themselves on the Right than are PostMaterialists - with the mixed types falling in between. But note that Cognitive Mobilization drives the Materialists and Post-Materialists in opposite directions: the mobilized
Materialists fall at the extreme Right of our seven groups, while the mobilized Post-Materialists place themselves to the Left of any group except the Revolutionaries. Not surprisingly, the Revolutionaries fall well to the Left of any other group. The fact that Cognitive Mobilization moves the Materialists and PostMaterialists in opposite directions seems logical: The Post-Materialists have, according to our hypotheses, emerged only recently and still constitute a minority group in societies that have, for some time, been largely oriented toward maximizing Materialist values. The Post-Materialists' basic priorities differ from those that predominate in their societies - and consequently, they are relatively likely to support social change, despite their relatively affluent backgrounds. The Materialists are in the opposite situation. Thus, Cognitive Mobilization drives the two groups in opposite directions because those with relatively high levels of cognitive skills presumably find it easier to select the ideological position that best expresses their underlying values.

This is only the first of several interaction effects associated with

\section{TABLE 8}

\section{Self-Placement on left-Right Scale by Groups In POLITICAL ORIENTATION TY- POLOGY* (MEAN SCORE SHOWN FOR EACH GROUP: $1.00=$ EXTREME LEFT, $10.00=$ EXTREME RIGHT)}

\begin{aligned} \hline $\begin{array}{l}\text { Non- } \\ \text { Mobilized }\end{array} & \left\{\begin{array}{lll}\text { Materialists } & 6.00(1920) \\ \text { Mixed } & 5.74(2011) \\ \text { Post-Materialists } & 5.13(224)\end{array}\right. \\$ Mobilized & $\left\{\begin{array}{lll}\text { Materialists } & 6.13(929) \\ \text { Mixed } & 5.70(1699) \\ \text { Post-Materialists } & 4.78(486) \\ \text { Revolutionaries } & 3.89(606)\end{array}\right.\end{aligned}$

* Fall, 1976 nine-station survey. 
our typology. We find a similar pattern in response to the question: "If there were a General Election tomorrow [to respondents under 18 , add: "And you had a vote"], which party would you support?" For purposes of cross-national comparisons, the political parties of the nine countries are coded as belonging to the Left, the Right, or as unclassifiable on this basis. In most countries the task is reasonably simple. In Great Britain and Germany, for example, the Labour and Social Democratic parties respectively are viewed as the Left, while the Conservative and Christian Democratic Parties make up the Right. In France, the parties of the Giscardien - Gaullist governing coalition-are considered to constitute the Right, while all major opposition parties make up the Left. In Italy, the picture is more complex, but there is general agreement that the Communists, Socialists and Social Democrats (and, usually, the tiny Republican Party) make up the Left, while the Christian Democrats, Liberals and Neo-Fascists are coded as Right. In the remaining countries, apart from Ireland, informed observers are able to say, with high intercoder reliability, which parties comprise the Left or Right. For Ireland the Left-Right dimension is almost meaningless, but we coded the Fine Gael party as Left on the grounds that it was allied with the Irish Labour Party - which can be placed on the Left with some confidence. By the process of elimination, this implied that the Fianna Fail must constitute the Irish Right.

Table 9 shows the percentages voting for the Right in the European Community as a whole. ${ }^{14} \mathrm{We}$

14. Table 9 combines results from the Fall 1976 and Fall 1977 surveys in order to
TABLE 9

Political Party Preference of Groups in POLITICAL ORIENTATION TYPOLOGY ${ }^{\star}$

(Percentage Supporting

PARTIES OF THE RIGHT)

\begin{tabular}{|c|c|c|c|}
\hline \multirow{2}{*}{$\begin{array}{l}\text { Non- } \\
\text { Mobilized }\end{array}$} & Materialists & \multicolumn{2}{|c|}{$59 \%(2882)$} \\
\hline & Mixed & 53 & $\begin{array}{r}(2746) \\
(289)\end{array}$ \\
\hline \multirow{4}{*}{ Mobilized } & $\mathrm{Ma}$ & 62 & (16 \\
\hline & Mix & 54 & (2591) \\
\hline & 0 & 33 & $(660)$ \\
\hline & Revolutionaries & 28 & (801) \\
\hline
\end{tabular}

* Combined Fall, 1976 and Fall, 1977 survey results.

find exactly the same type of interaction effect here as in connection with the respondents' description of their political views. The mobilized Materialists are the most conservative of any group (62 percent of them reporting that they would vote for a party of the Right) while the mobilized Post-Materialists are the most Left-oriented of any group -except the Revolutionaries. Figure 8 gives a graphic presentation of the effects of values and Cognitive Mobilization on Left-Right ideological self-placement and on Left-Right voting interactions. The interaction effects visible here indicate that in a simple additive model, the political impact of both values and cognitive skills would tend to be underestimated.

In everything we have seen up to this point, the Revolutionaries resemble the Post-Materialists - especially the mobilized ones. Similar in social background characteristics, in ideological self-placement,

compensate for relatively large amounts of missing data due to nonresponse and because Centrist parties, such as the British Liberals, or nonclassifiable parties, such as the Belgian ethnic separatists, are excluded from these tables. 
(a) Meon Self-Placement on Left-Right Ideology Scole:

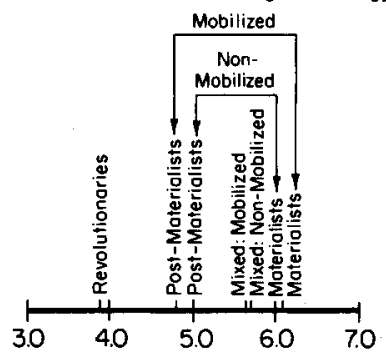

(b) Percentage Voting for Porties of the Right:

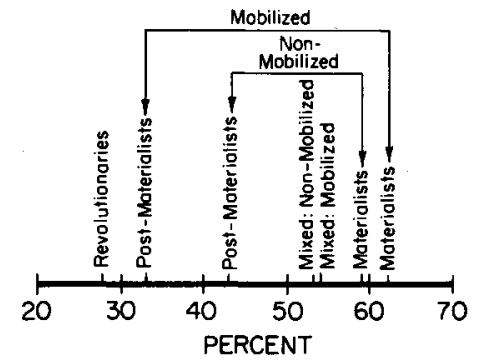

FIGURE 8

LOCATION ON LEFT-RIGHT DIMENSION OF Groups in POLITICAL ORIENTATION TYPOLOGY.

and in their political party preferences, one might be tempted to conclude that the Revolutionaries are just like the Mobilized PostMaterialists, only more so. This conclusion would be mistaken. Though they overlap in many respects, the Revolutionaries are a highly distinctive type-and in some ways they lie at the opposite end of the continuum from the Mobilized Post-Materialists. This fact is particularly relevant to our central interest in this article-public attitudes toward European integration. For the European integration movement is a Reformist strategy par excellence. It is supported by those who wish to improve the existing social order, more than by those who seek to defend the status quo. But the Revolutionaries constitute a group that is dedicated to abolishing the existing system, not repairing it. For the Revolutionary Left, reforming the system is merely a way to ward off total overhaul: viewed in this light, European integration may seem counterproductive.

Table 10 shows the percentages making positive assessment of Common Market membership among the seven groups in our typology. In contrast with the two preceding tables, in which Revolutionaries and Mobilized Post-Materialists occupy adjacent positions, here they fall at opposite ends of the spectrum. Another contrast with the preceding tables is the fact that here, Cognitive Mobilization and value priorities have additive effects, with favorable assessments rising in a smooth progression as we move from the nonmobilized Materialists, at the low extreme, to the Mobilized Post-Materialists, who make the most favorable assessments. But the Revolutionaries rank lowest of any group, with a percentage of favorable assessments that puts them substantially below the non-Mobilized Materialists - in other respects the group they resemble least.

Is this an isolated phenomenon?

TABLE 10

APPRAISAL OF EUROPEAN COMMUNITY MEMBERSHIP BY GROUPS IN POLITICAL ACTION TYPOLOGY* (PERCENTAGE SAYING That Their Country's MeMBERSHIP IS A GOOD THING)

\begin{tabular}{|c|c|c|}
\hline $\begin{array}{l}\text { Non- } \\
\text { Mobilized }\end{array}$ & $\begin{array}{l}\text { Materialists } \\
\text { Mixed } \\
\text { Post-Materialists }\end{array}$ & $\begin{array}{lr}55 \% & (2023) \\
57 & (2105) \\
63 & (190)\end{array}$ \\
\hline \multirow[t]{2}{*}{ Mobilized } & $\begin{array}{l}\text { Materialists } \\
\text { Mixed } \\
\text { Post-Materialists }\end{array}$ & $\begin{array}{lr}64 & (1172) \\
69 & (1962) \\
78 & (400)\end{array}$ \\
\hline & Revolutionaries & (518) \\
\hline
\end{tabular}

* Fall, 1977 Survey, weighted according to population. 
Let us compare the proportions who feel that their representatives in the European Parliament should act for the good of the Community as a whole, even if it conflicts with the national interest. Table 11 provides the relevant data. And the basic pattern is similar to what we have just seen. Willingness to give priority to the interests of the Community is lowest among nonmobilized Materialists and reaches its peak among the mobilized PostMaterialists. But the impact of value type dominates that of Cognitive Mobilization: the mobilized Materialists are more European than nonmobilized ones, and the same thing is true of each of the other value types when we compare the mobilized with the nonmobilized group. But the effect of Cognitive Mobilization alone is not great enough to raise all of the mobilized types above the nonmobilized ones.

The results of these analyses help clarify the complex relationship between support for European integration and Left-Right dimension. For both Left and Right have several distinct constituencies, drawing varying amounts of support

TABLE 11

NATIONAL INTEREST VS. EUROPEAN COMMUNITY Interest by Groups in Political OrientaTION TYPOLOGY* (PERCENTAGE Giving PRIORITY to EUROPE AS A WHOLE)

\begin{tabular}{|c|c|c|c|}
\hline $\begin{array}{l}\text { Non- } \\
\text { Mobilized }\end{array}$ & $\begin{array}{l}\text { Materialists } \\
\text { Mixed } \\
\text { Post-Materialists }\end{array}$ & $\begin{array}{l}45 \\
51 \\
66\end{array}$ & $\begin{array}{r}(1963) \\
(2013) \\
(185)\end{array}$ \\
\hline \multirow[t]{2}{*}{ Mobilized } & $\begin{array}{l}\text { Materialists } \\
\text { Mixed } \\
\text { Post-Materialists }\end{array}$ & $\begin{array}{l}56 \\
63 \\
78\end{array}$ & $\begin{array}{r}(1164) \\
(1854) \\
(389)\end{array}$ \\
\hline & Revolutionaries & 50 & (499) \\
\hline
\end{tabular}

* Fall, 1977 survey, weighted according to population. from each of our seven types. One major group is Materialist, concerned primarily with attaining-or defending-economic and physical security. For this group, it seems likely that support for European integration has had particularly strong linkages with the perception that it was associated with prosperity. In the uncertain setting of the late 1970's, this component of support was relatively weak. Both mobilized and nonmobilized Materialists made comparatively negative assessments of Community membership, and were relatively hesitant to let the interests of the Community as a whole take precedence over their own country's immediate interests. For the PostMaterialists, on the other hand, European integration's appeal may be rooted to a greater extent in concerns for human solidarity, even apart from its economic effects. This is not to say that concerns for solidarity were unimportant to those with Materialist or Mixed values; it is simply a question of the relative weights.

The Revolutionaries are a special case. Like the Post-Materialists, they tend to support social change; accordingly, both groups place themselves on the Left of the political spectrum. But the two groups' ideological perspectives differ. For the Reformist Left, the construction of a supranational European Community, aimed at superseding the nationstate, may seem a major advance having farreaching implications. For the Revolutionary Left, it may seem like a diversion or even a hindrance to more drastic forms of change. The two groups part company on this issue, with the Revolutionary Left taking a position adjacent to that of the nonmobilized Materialists. Ironically, a Reaction- 
ary impulse was particularly strong among the latter group. Although its members have lower levels of income and education than any other group, which previously might have tied them more strongly to the Left, in 1977 advocates of " $a$ valiant defense of the present society against all subversive forces" vastly outweighed proponents of revolutionary change. The nonmobilized Materialists were concerned by the current crisis, but were more apt to see the solution in a restoration of the prosperous industrial society they had known in the recent past, than in revolutionary change. For opposite reasons, the Revolutionaries and nonmobilized Materialists were reluctant to support European integration.

The relationship between LeftRight political preferences and support for European integration is complex. While the Reformist Left is markedly favorable, the Revolutionary Left tends to be suspicious. But the complexity does not end there, because one finds striking cross-national differences in the degree to which the supporters of the Left and Right hold positive attitudes toward the Community. Table 12 gives some evidence on this score. In Italy, the country with the largest Communist Party in Western
Europe, the Left is highly favorable to EEC membership; this holds true of both Communist and Socialist electorates, when we analyze them separately. Clearly, we cannot equate the Revolutionary Left with support for the Communist Party. Most Italian Communists are non-Revolutionary. In Germany, where the Social Democrats have been in power since 1969 (and have shared power since 1966), the electorate of the Left is somewhat more favorable to the Community and to European solidarity than the electorate of the Right. Overall, there is a clear correlation between support for the parties in office-whether of the Left or the Right-and support for the Community. When the Left has been in power for some period of time, there is a tendency for its supporters to identify with its policies, including support for European integration, if that is one of them. Accordingly, in the Netherlands, where a coalition headed by the Left was in office from 1972 to 1977, the differences between supporters of the Left and Right are negligible; in earlier surveys, the electorate of the Left was slightly more favorable to European integration than that of the Right.

Political party cleavages on this issue are greatest by far in Denmark,

TABLE 12

Appraisal of European Community Membership by Political Party Preference by Nation* (Percentage Saying Their Country's Membership is a Good Thing)

\begin{tabular}{|c|c|c|c|c|c|c|c|c|}
\hline $\begin{array}{c}\text { RESPONDENT } \\
\text { SUPPORTS } \\
\text { A PARTY } \\
\text { OF THE: }\end{array}$ & France & Belg. & Neth. & Ger. & ITALY & DEN. & IRE. & UK \\
\hline Left & $58 \%$ & 63 & 77 & 67 & 72 & 26 & 59 & 33 \\
\hline Center & 61 & 77 & - & 74 & 58 & 38 & - & 33 \\
\hline Right & 72 & 84 & 80 & 61 & 80 & 66 & 64 & 45 \\
\hline Don't Know & 58 & 65 & 74 & 70 & 73 & 28 & 60 & 29 \\
\hline
\end{tabular}

* Fall, 1977 survey, weighted according to population. 
one of the new member countries. Here, the polarization between Left and Right is immense; a gulf of 40 percentage points separates the two electorates. This polarization dominates all other variables, including the Political Orientation typology. In the nine nations as a whole, this typology is the strongest individuallevel predictor of one's assessment of membership and of support for European over national interests. In Denmark, both political party preference and occupation of head of household have stronger explanatory power than does the typology. In general, the effects attributable to the Political Orientation typology are weaker in the three new member countries than in the original six. As was noted above, the impact of the immediate environment tends to be greater in the new member countries than in the old; and both value type and level of Cognitive Mobilization are, theoretically, relatively stable characteristics of given individuals.

To a limited extent-though only a limited one-our indicators of values and cognitive levels help explain the long-term continuity in favorable assessments of EEC membership that was noted in the first part of this article. When we aggregate mean scores on our values index to the national level, the result shows a correlation of .457 with favorable assessments of membership across the nine nations across time. Similarly aggregated to the nation level, our index of Cognitive Mobilization has a .356 correlation. ${ }^{15}$

15. It should be noted that these figures are somewhat less reliable than those in our earlier aggregate analyses, because neither the values indicator nor the Cognitive Mobilization indicator was included in all the surveys conducted since 1973. Our N's in the present correlations fall to 45 and 63,
These correlations are somewhat stronger than those obtained with any of the economic indicators discussed in the earlier section.

Both Post-Materialist values and high levels of Cognitive Mobilization are somewhat more prevvalent among the publics of the original Six than among the Three-probably a reflection of the fact that the three new members have somewhat lower economic levels: while Denmark is highly prosperous, both Ireland and Britain rank at or near the bottom of the Community rankings in gross domestic product per capita. Nevertheless, we should not make too much of these findings. When we add these two variables to a multiple regression that includes the economic indicators discussed previously, and the dummy variable based on early versus late membership, the latter variable remains - by far - the strongest predictor of favorable or unfavorable assessments of the Community. ${ }^{16}$ The effects attributable to value type and to Cognitive Mobilization levels may contribute to the stability of attitudes observed at the aggregate level. They do not explain away the effects associated with sheer length of membership.

We have examined the degree to which various groups make favorable or unfavorable assessments of membership in the EEC, and the degree to which they feel that representatives to the European Parliament should work on behalf of Com-

respectively. Even with these reduced N's, the relationships are significant at better than the 01 level, however.

16. In principle, a multistage causal model would be desirable here, but in view of our reduced N's we will not press the data any farther. It seems advisable to wait until the results from additional surveys become available. 
TABLE 13

EXPECTED RATE OF PARTICIPATION IN ELECTIONS TO EUROPEAN PARLIAMENT, BY POLITICAL ORIENTATION TYPOLOGY* (PERCENTAGE SAYING THEY WILl CERTAINLY or Probably Vote)

\begin{aligned} \hline \hline $\begin{array}{c}\text { Non- } \\ \text { Mobilized }\end{array} & \left\{\begin{array}{lrr}\text { Materialists } & 70 \% & (2272) \\ \text { Mixed } & 67 & (2359) \\ \text { Post-Materialists } & 73 & (206)\end{array}\right. \\$ Mobilized & $\left\{\begin{array}{llr}\text { Materialists } & 84 & (1227) \\ \text { Mixed } & 84 & (1997) \\ \text { Post-Materialists } & 89 & (410) \\ \text { Revolutionaries } & 65 & (556)\end{array}\right.\end{aligned}$

* Fall, 1977 survey, weighted according to population.

munity interests, or those of one particular nation. In 1979 the publics of the nine countries will have a chance to elect representatives pledged to act on behalf of given viewpoints. Will they take this opportunity?

One might expect those who are least enthusiastic about Community membership to show the lowest rates of turnout in the elections to the European Parliament, and to some extent this is the case. Table 13 shows the percentage saying (in Fall 1977) that they would certainly or probably vote in these elections, among each of the seven groups in our typology. Here, the effects of Cognitive Mobilization dominate those of value type, but within each cognitive level the Post-Materialists are most likely to vote, and the Revolutionaries seem least likely to vote. Being a group that otherwise shows quite high levels of political interest and partisan attachment, this tendency on the part of the Revolutionaries may change as the election campaign gets under way. ${ }^{17} \mathrm{~A}$ year and a

17. This statement needs to be qualified. In the Community as a whole, the Revolu- half before the elections, the Revolutionary type showed a markedly low intention to vote.

This was not true of the Left in general, however. Though they were somewhat less favorable than the Right in their assessments of Community membership, the supporters of the Left showed a slightly higher rate of certain or probable voting expectations. The Left's relatively high expected turnout seems to reflect differential rates of party identification-for whether or not one will vote seems to depend, above all, on whether or not one feels a sense of attachment to some political party. Table 14 shows the expected rates of turnout, according to strength of party attachments. It appears that partisan cues will play a double role in shaping the

TABLE 14

\section{EXPECTED RATE OF PARTICIPATION IN ELECTIONS to European Parliament, by Party IDENTIFICATION* (PERCENTAGE SAYING THEY Will CERTAinly or Probably Vote)}

Question: "Do you consider yourself a supporter of any particular political party? (If YES): Do you feel yourself to be very involved in this party, fairly involved or merely a sympathizer?"

$\begin{array}{llr}\text { Very involved } & 85 \% & (867) \\ \text { Fairly involved } & 83 & (1647) \\ \text { Merely a sympathizer } & 80 & (3146) \\ \text { No affinity with any Party } & 63 & (2922)\end{array}$

- Fall, 1977 survey, weighted according to population.

tionaries show substantially higher levels of Cognitive Mobilization and attachment to political parties than does the population at large. Neither of these characteristics applies to the Revolutionaries in our samples from the United Kingdom or the Republic of Ireland. The relative weakness of a Marxist tradition in the British Isles seems to give support for revolutionary change a different significance from what it has on the Continent. 
character of the new European Parliament. To an extent that varies greatly from nation to nation, they seem relevant to whether one emphasizes a European or a national frame of reference. In all nine countries, they seem highly relevant to whether or not one will vote in the European elections.

\section{CoNClusion}

Public assessments of the benefits of membership in the Common Market wavered in the face of the economic crisis that took place shortly after expansion of the Community, and it seems possible to attribute some of the ups and downs to specific economic factors. But these assessments showed more stability than one might have expected, given the severe economic perturbations that took place. In part this stability seems linked with long-term developments in the values and cognitive skills of Western publics. To an even greater degree it seems to reflect whether a given public has experienced membership in the Community for a relatively long or a relatively short period of years. Even among the publics of the three new countries, there are indications of a growing sense of Community solidarity. A readiness to pursue the common good rather than simply the immediate interests of a particular nation is already fairly widespread among the publics of the European Community. Whether the political leaders of the nine nations will act to encourage or to diminish this sense of solidarity remains to be seen. 